https://doi.org/10.46344/JBINO.2021.v10i03.02

\title{
DECOLORIZATION OF DYES DIRECT RED 31 (DR 31); DIRECT BLUE 71 (DB 71) AND DIRECT BLACK 19 (DB 19) BY NEWLY ISOLATED Bacillus sp. DM1
}

\author{
Gulati Deepti ${ }^{*}$, Gunwant Monika²
}

I*Associate Professor, Department of Biotechnology, Dolphin (PG) Institute of Biomedical and Natural Sciences, Dehra Dun-248007, Uttarakhand, India

2Department of Biotechnology, Dolphin (PG) Institute of Biomedical and Natural Sciences, Dehra Dun-248007, Uttarakhand, India

email id: deepti gulati01@yahoo.co.in

\section{ABSTRACT}

In this study, the decolorization potential of novel Bacillus sp. DM 1 isolated from textile effluents was evaluated. Decolorization of direct red 31 dye was $89 \%$ ( \pm 1.20$)$; direct blue 71 dye was 90\% ( \pm 0.84 ) and direct black 19 dye was $81 \%$ ( \pm 0.39 ) after 24 hours at 100 ppm concentration. It took 48 hours for nearly complete decolorization of red and blue dyes and 72 hours for black dye. Dextrose showed $97 \%( \pm 0.91)$ decolorization of blue dye, sucrose $95 \%( \pm 1.11)$ decolorization of black dye and lactose $98 \%( \pm 1.35)$ decolorization of red dye. Yeast extract showed $94 \%( \pm 0.80)$ and $97 \%( \pm 0.43)$ decolorization of black and red dye respectively, whereas sodium nitrate showed $95 \%$ ( \pm 0.73 ) decolorization of blue dye. $\mathrm{pH} 7$ and temperature $35^{\circ} \mathrm{C}$ was found optimum for decolorization of the dyes. $7 \%$ inoculum size for red and blue dye and $8 \%$ for black dye were optimum.

Keywords: Bacillus sp., Bioremediation, Direct black, Direct blue, Direct red, Effluent treatment 


\section{Introduction}

Due to rapid industrialization, lots of chemicals including dyes are manufactured and used in day to day life (Moosvi et al., 2005). During the dyeing process $2 \%$ of these dyes fail to bind to the substrate and are discharged in aqueous effluents (Ndasi et al., 2011). The wastewater from textile when directly released in the surface water without treatment can cause a rapid depletion of dissolved oxygen and lead to a great environmental damage (Ramasany et al., 2012). Synthetic dyes used most commonly in the textile industry for dyeing clothes is the major source of polluting our water resources. Water pollution has been recognized as the major hazard of the modern world and is one of the main cause of death and disease (Pratiwi et al., 2017). Pollution caused by dye effluent is mainly due to durability of the dyes in wastewater (Jadhav et al., 2007). Therefore, the removal of dyes from textile effluents is a major concern for protection of environment. Existing methods for decolorization of dyes in waste water include $\mathrm{pH}$ neutralization, membrane filtration, irradiation, ozonation, adsorption on activated carbon, oxidation, reverse osmosis, electrocoagulation, flocculation but these methods are inefficient, expensive and lead to development of waste in the form of sludge which again needs to be disposed off (Keharia and Madamwar, 2003; Ogugbue and Sawidis, 2011). Dyes are difficult to degrade because of their color fastness, synthetic origin and complex aromatic molecular structures which make them stable (Fu and Viraraghavan, 2001; Anjaneyulu et al., 2005). Microbial decolorization and degradation of azo dyes has gained considerable interest of researchers as it is inexpensive, eco-friendly, and produces less amount of sludge (Parshetti et al., 2006). In recent years work has been done to isolate microorganisms capable of decolorizing textile wastewater (Chen et al., 2003; Coughlin et al., 2002; Gurulakshmi et al., 2008; Joshi and Saxena, 2018; Kalyani et al., 2009; Lalnunhlimi and Krishnaswamy, 2016; Patel et al., 2017; Shah et al., 2014). But in most of the studies the rate of decolorization is low and/or the isolates take many days to degrade the dye, for example, Alcaligenes aquatilis was found to decolorize $82 \%$ Synazol red $6 \mathrm{HBN}$ after incubation of 4 days at $37^{\circ} \mathrm{C}$ and $\mathrm{pH} 7$ (Ajaz et al., 2019). Bacillus sp. and Pseudomonas sp. have showed $89 \%$ of decolourization of Orange $3 \mathrm{R}$ at $144 \mathrm{~h}$ followed by 80 and $76 \%$ by Salmonella sp. and Klebsiella sp., respectively (Ponraj et al., 2011). Pseudomonas aeuroginosa has been reported to decolorize remazol black B from 85 to $94.4 \%$ after 5 days (Junior et al., 2015). The overall aim of this research work was therefore to isolate bacterial strains that show high decolorization potential and to develop a fast, enhanced and cost efficient method to degrade dyes released from the textile processes.

\section{Material and Methods}

\section{Selection of dyes}

Direct red 31 (DR 31), direct blue 71 (DB 71) and direct black 19 (DB 19) dyes, 2021 May Edition | www.jbino.com | Innovative Association 
widely used for dyeing, were purchased from textile industry. For convenience common name of the dyes used in this study are used. All media and chemicals used in the study were of analytical grade and purchased from Hi-media, India. Medium with dyes was used as control.

Isolation of bacteria from textile dye effluent

One $\mathrm{ml}$ of each of the textile effluent samples from Selaqui Industrial area, Dehra Dun were mixed in water blank and was then serially diluted from $10^{-1}$ to $10^{-9}$. All dilutions were plated on nutrient agar media and incubated at $37^{\circ} \mathrm{C}$ for 24 hours. Morphologically distinct colonies so obtained were then streaked on nutrient agar medium. Bacterial pure culture was maintained in nutrient agar medium slants and stored at $4^{\circ} \mathrm{C}$ and was sub cultured every month.

\section{Determination of dye spectrum}

Absorption of Red, Blue, Black dyes and textile effluent between wavelengths 400$700 \mathrm{~nm}$ were read to determine the wavelengths that showed the maximum absorbance. Decolorization of respective dyes was measured on the basis of decrease in absorbance at the determined wavelength.

\section{Preliminary screening for dye decolorization ability}

\section{Liquid culture assay}

For liquid culture dye decolorizing experiment, sterile nutrient broth supplemented with 100 ppm dyes was inoculated with bacterial cultures and incubated for 24 hours at $37^{\circ} \mathrm{C}$. Extent of dye decolorization was assessed spectrophotometrically and the rate of decolorization was calculated using the following formula as described by Sani and Banerjee, 1999

Decolorization $(\%)=\frac{\text { Initial absorbance }- \text { Final absorbance }}{\text { Initial absorbance }} \times 100$

\section{Characterization of bacterial isolate}

Characterization was done on the basis of colony morphology in plate, slant and broth. For characterization of cell morphology simple, gram, acid fast, negative and capsule staining was done. Indole production, Methyl Red-Voges Proskaver, Citrate, Hydrogen Sulfide production, Catalase, Oxidase, Amylase, Carbohydrate fermentation, Nitrate tests were performed for biochemical characterization.

\section{Optimization of culture conditions}

a. Effect of dye concentration on decolorization

Nutrient media was amended with the selected dye at a concentration of 25 to 800 ppm. After different time intervals, aliquot $(1.5 \mathrm{ml})$ of the culture media was withdrawn, centrifuged and supernatant obtained was used for analysis of \% decolorization spectrophotometrically at optimum wavelengths. 


\section{b. Effect of time of incubation on dye decolorization}

Nutrient media with dye concentration 100 ppm was inoculated with the test organism. The culture was incubated for 96 hours at $37^{\circ} \mathrm{C}$. The result of decolorization was observed spectrophotometrically.

\section{c. Effect of $\mathrm{pH}$ on dye decolorization}

Nutrient media at different $\mathrm{pH}(3,4,5,6$, 7,8 , and 9) with each dye concentration $100 \mathrm{ppm}$ was inoculated with bacterial culture at optimum time of incubation for each dye. The result of decolorization was observed spectrophotometrically.

d. Effect of temperature on dye decolorization

Nutrient media prepared at optimum conditions, supplemented with dye was incubated at different temperatures ranging from $25^{\circ} \mathrm{C}$ to $65^{\circ} \mathrm{C}$. The result of decolorization was observed spectrophotometrically.

\section{e. Effect of carbon and nitrogen sources} on dye decolorization

Minimal broth medium $\left(\mathrm{KH}_{2} \mathrm{PO}_{4} 2.0, \mathrm{NaCl}\right.$ 0.5, $\mathrm{MgSO}_{4}$ 0.2, $\mathrm{CaCl}_{2}$ 0.02, $\left(\mathrm{NH}_{4}\right)_{2} \mathrm{SO}_{4} 1.0$ $\mathrm{g}^{-1}$ ) was supplemented with $1 \%$ concentration of carbon and nitrogen sources respectively. Peptone, sodium nitrate, yeast extract and ammonium nitrate were used as nitrogen source. Maltose, dextrose, sucrose and lactose were used as carbon source.

\section{f. Effect of inoculum size on dye decolorization}

Inoculum size ranging from $1 \%$ to $10 \%$ was prepared containing media supplemented with bacterial isolate. The result of decolorization was observed spectrophotometrically.

\section{Screening for azoreductase}

The bacterial cell pellet was suspended in $0.1 \mathrm{M}$ phosphate buffer $(\mathrm{pH} 7.2)$ and 0.5 $\mathrm{w} / \mathrm{v}$ Triton-X 100 was added. The mixture was incubated at $4^{\circ} \mathrm{C}$ for 30 minutes with continuous stirring followed by centrifugation at $10000 \mathrm{rpm}$ for 25 minutes. The supernatant was used as crude enzyme extract for the assay. The azoreductase assay was carried out according to the procedure of Liger et al., 2004. The reaction mixture $(2 \mathrm{ml})$ contained $35 \mu \mathrm{M}$ azo dye, $100 \mu \mathrm{M}$ NADH, $20 \mu \mathrm{M}$ FMN, and $2.4 \mu \mathrm{M}$ of enzyme in 25 $\mathrm{mM}$ Tris- $\mathrm{HCl}(\mathrm{pH} 7.5)$. The reaction was run at $30^{\circ} \mathrm{C}$, and the decrease in absorbance at optimal wavelength for each azo dye tested as a substrate was monitored: direct red 31 dye at $520 \mathrm{~nm}$, direct blue 71 dye at $625 \mathrm{~nm}$ and direct black 19 dye at $620 \mathrm{~nm}$. Total protein was estimated using the standard Lowry's method (Lowry et al., 1951). One-unit enzyme activity was calculated as one umole of dye reduced per minute. Specific enzyme activity was calculated as unit permg.

\section{Statistical analysis}

All experiments were performed in triplicates. Results are reported as mean \pm S.E (Standard Error Mean).

Results and Discussion

Isolation and screening of bacterial strains

A total of 13 morphologically distinct strains isolated from effluent samples were screened for decolorization of the 
dyes. Three showed good decolorization activity but eventually one isolate showing maximum activity for all the three dyes was selected for further experimentation. The selected isolate was characterized morphologically in agar plate, broth and slant followed by biochemical characterization. This novel Bacillus sp. DM1 showed 89\% ( \pm 1.20$)$ decolorization of direct red 31 (DR 31) dye; $90 \%$ ( \pm 0.84) for direct blue 71 (DB 71) dye and $81 \%( \pm 0.39)$ for direct black 19 (DB 19) dye after 24 hours incubation at 100 ppm dye concentration. The absorption maxima of the direct red 31 dye was found to be $520 \mathrm{~nm}$, direct blue 71 dye $625 \mathrm{~nm}$, direct black 19 dye 620 $\mathrm{nm}$ and textile effluent $410 \mathrm{~nm}$. Preliminary studies showed the necessity for optimizing process parameters and therefore parameters such as $\mathrm{pH}$, temperature, time of incubation, dye concentration and inoculum size were optimized. Nutritional parameters such as carbon and nitrogen sources were also optimized.

\section{Optimization of culture conditions}

Textile dye degradation using the isolated test organism was optimized under different conditions and parameters.

\section{a. Effect of dye concentration on $\%$ decolorization}

The decolorization of all three dyes was studied at different dye concentrations ranging from $25 \mathrm{ppm}$ to $800 \mathrm{ppm}$. Maximum decolorization was observed at 100 ppm (Figure 1).

\section{b. Effect of time of incubation on \% dye decolorization}

The decolorization efficiency of Bacillus sp. recorded up to 96 hours of incubation showed maximum decolorization at 48 hours for red $(94 \% \pm 0.95)$ and blue dye $(96 \% \pm 0.46)$. Thereafter increasing incubation time showed little change in decolorization efficiency. Black dye was $97 \% \pm 0.17$ decolorized after 72 hours of incubation (Figure 2).

\section{c. Effect of $\mathrm{pH}$ on \% dye decolorization}

The isolate was able to decolorize the dyes over a wide range of $\mathrm{pH}$. However, maximum decolorization was recorded at pH 7 for all the three dyes (Figure 3).

\section{d. Effect of temperature on \% dye decolorization}

Optimal temperature for decolorization of all dyes was $35^{\circ} \mathrm{C}$. Decolorization rate dropped sharply as the temperature increased from $35^{\circ} \mathrm{C}$ to $65^{\circ} \mathrm{C}$ (Figure 4).

\section{e. Effect of carbon sources on \% dye decolorization}

Among the sources studied dextrose showed $97 \%( \pm 0.91)$ decolorization of blue dye, sucrose showed 95\% ( \pm 1.11) decolorization of black dye and lactose showed 98\% ( \pm 1.35) decolorization of red dye (Figure 5).

\section{f. Effect of nitrogen sources on \% dye decolorization}

Among the sources studied yeast extract showed maximum decolorization of black and red dye with $94 \%( \pm 0.80)$ and $97 \%( \pm$ $0.43)$ respectively, whereas sodium nitrate showed $95 \%$ ( \pm 0.73) decolorization of blue dye (Figure 6).

g. Effect of inoculum size on $\%$ dye decolorization

With inoculum size ranging from $1-10 \%$, it was observed that red and blue dye showed 95\% ( \pm 0.42) and 96\% ( \pm 0.26$)$ 2021 May Edition | www.jbino.com | Innovative Association 
decolorization, respectively, in $7 \%$ showed $98 \%( \pm 1.33)$ decolorization in $8 \%$ inoculum size, whereas black dye inoculum size (Figure 7).

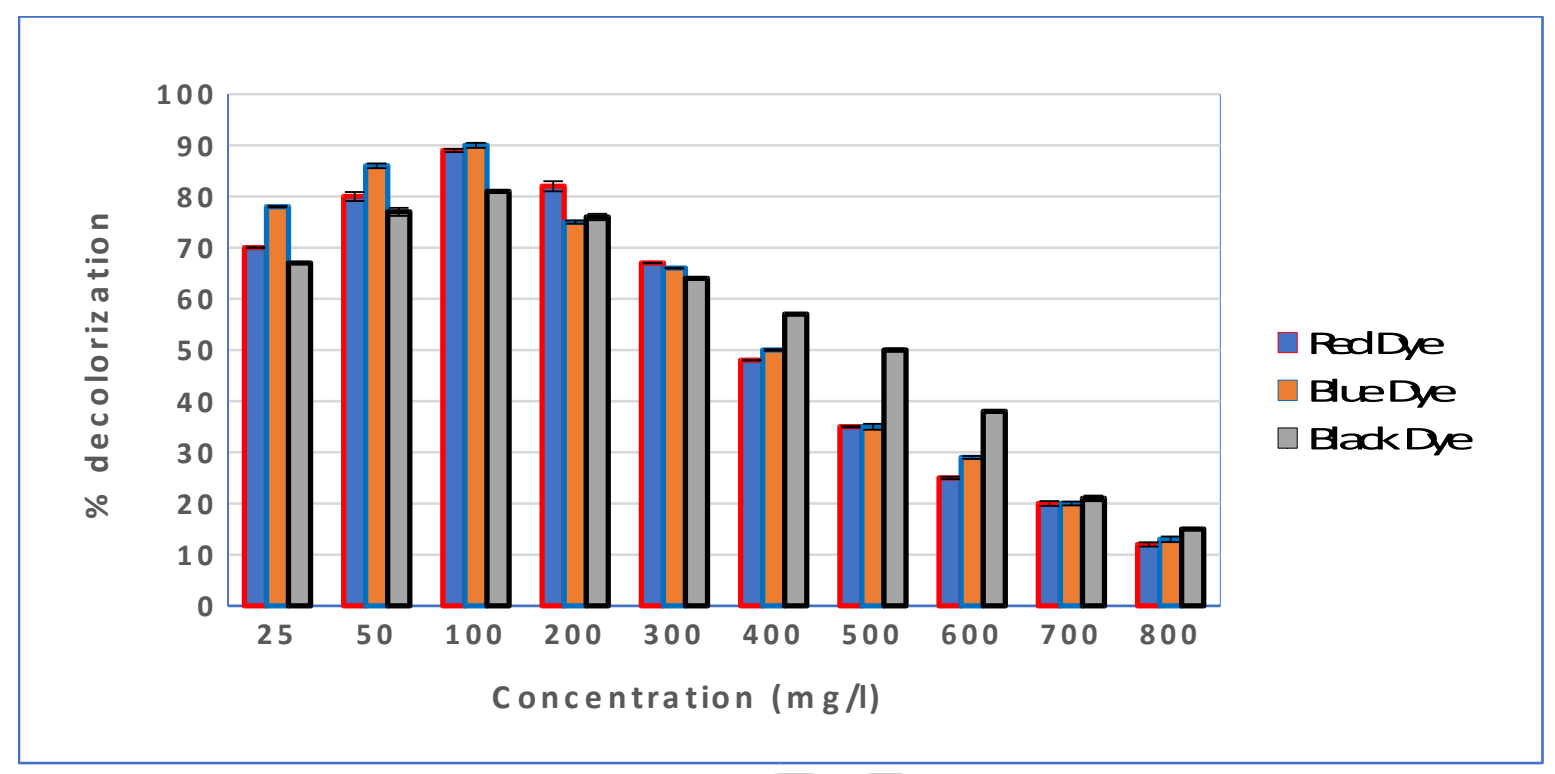

Figure 1: Effect of dye concentration on \% decolorization

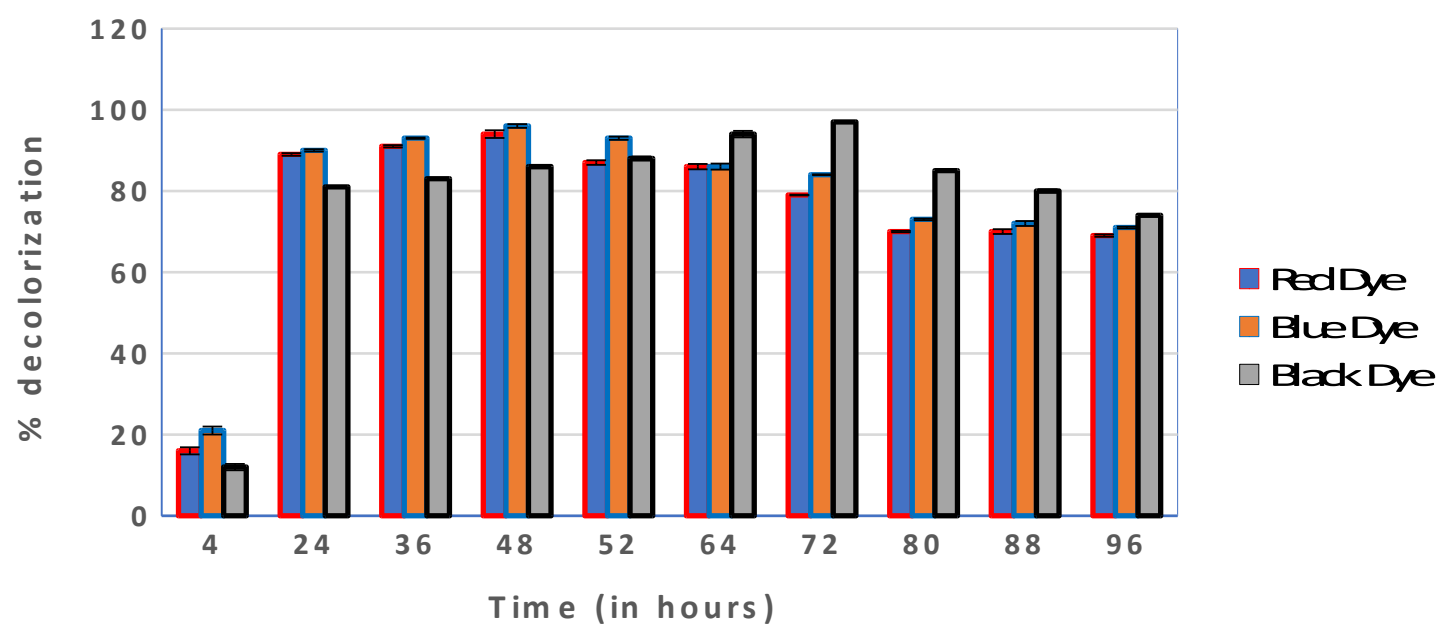


Figure 2: Effect of time of incubation on \% dye decolorization

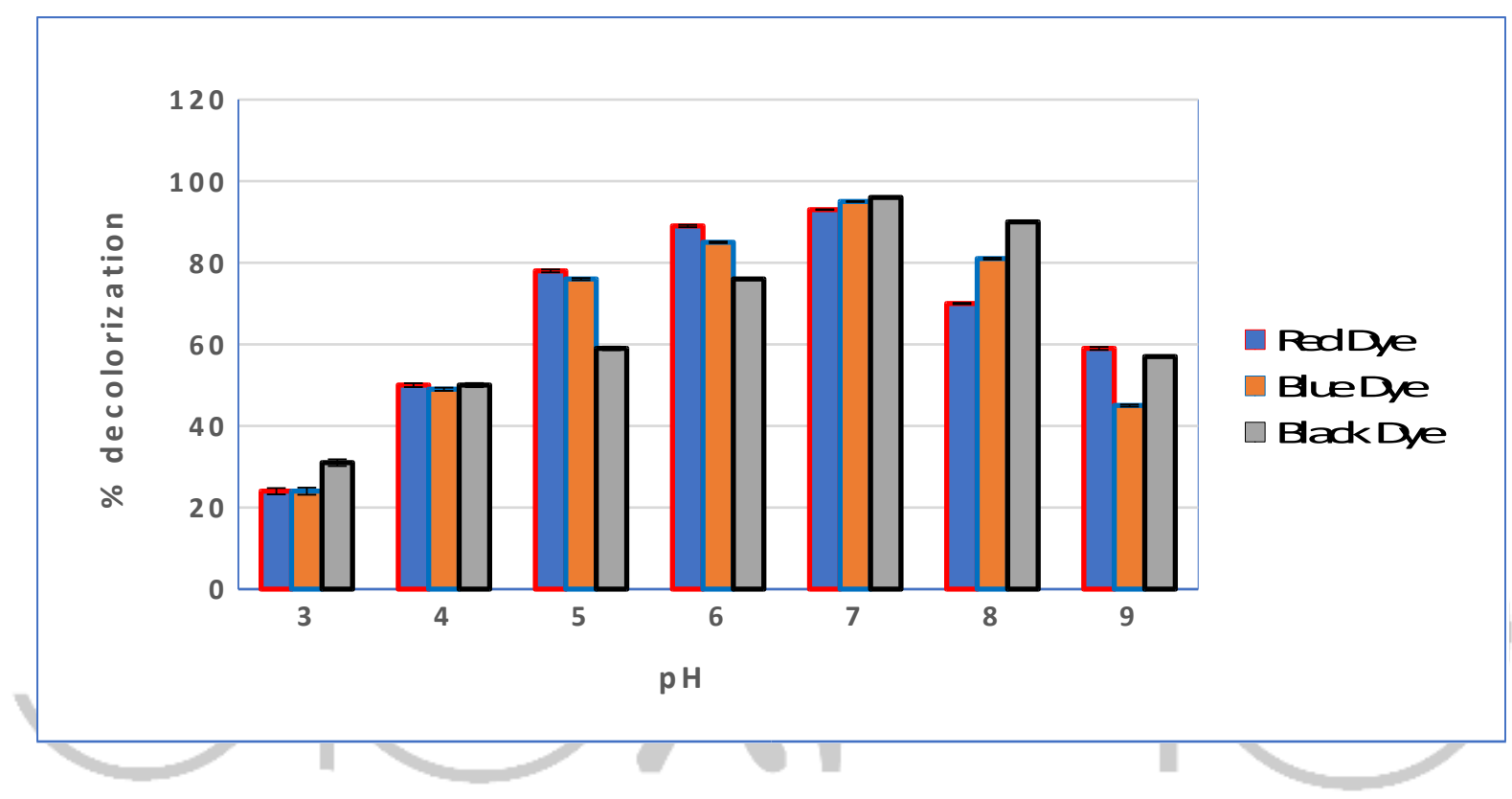

Figure 3: Effect of pH on \% dye decolorization

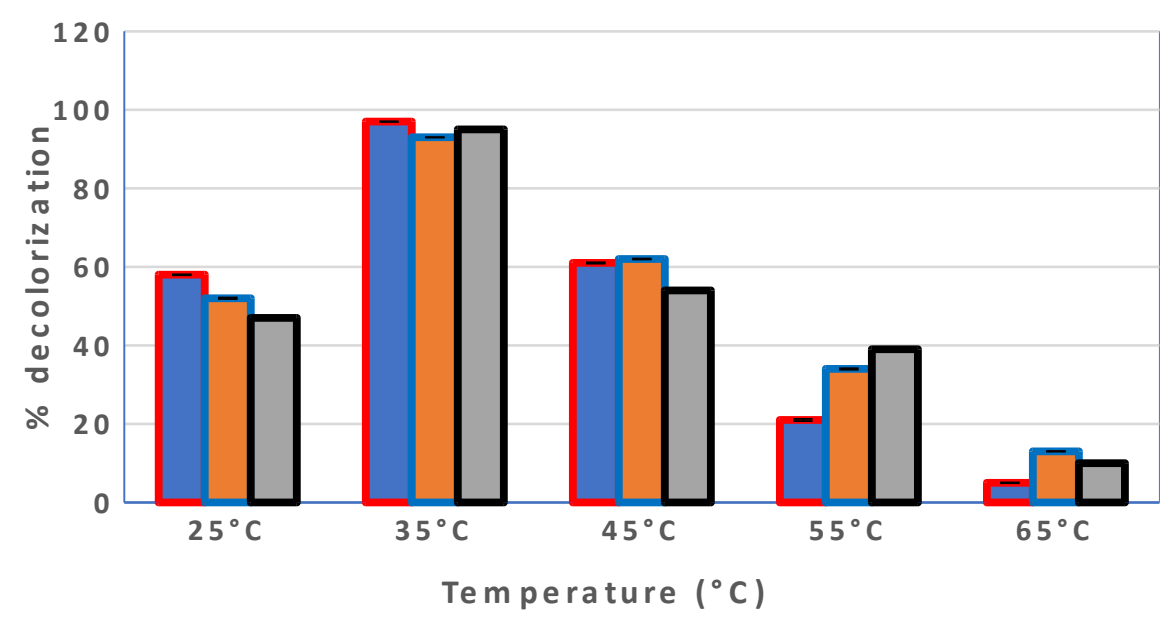


Figure 4: Effect of temperature on \% dye decolorization

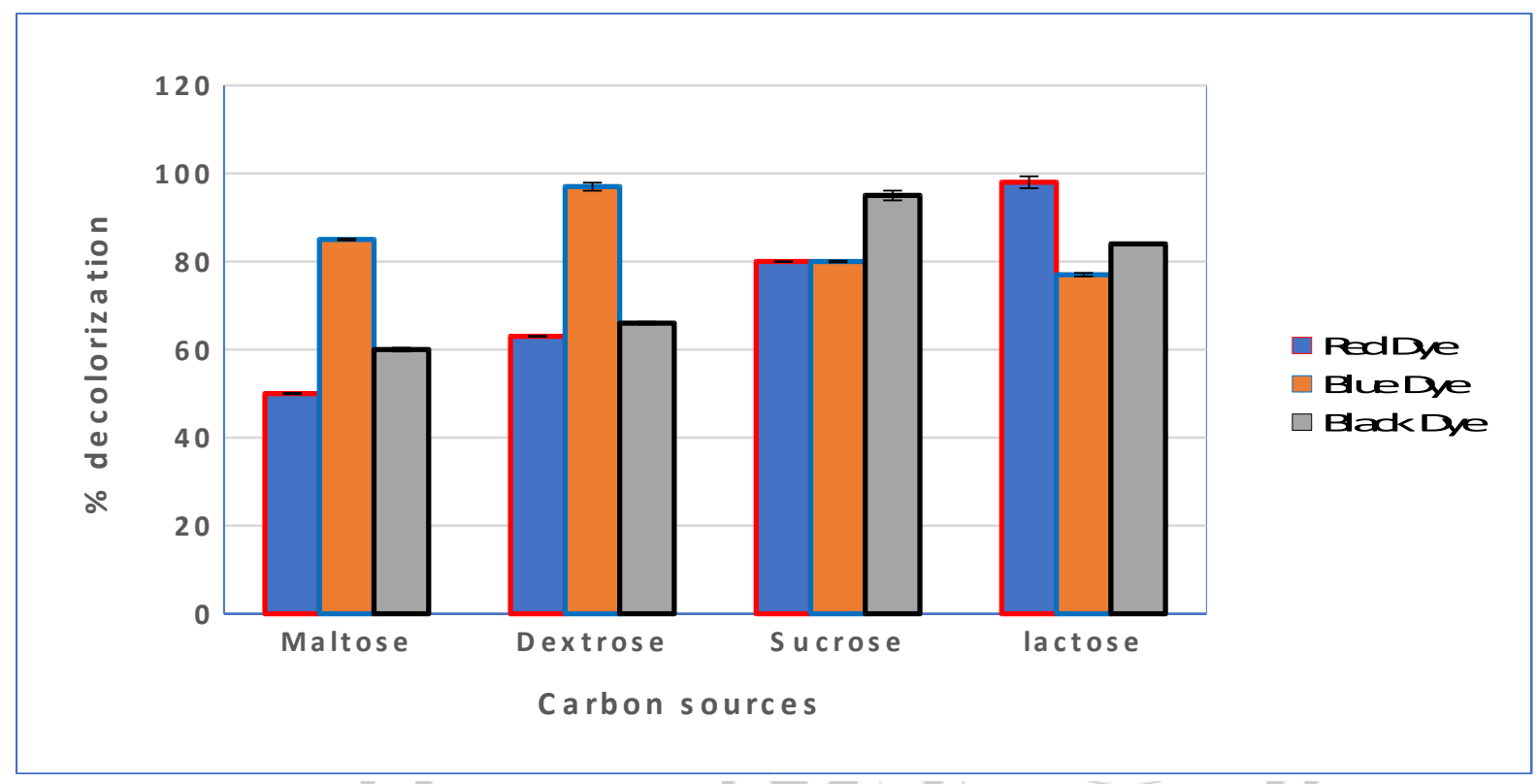

Figure 5: Effect of carbon sources on \% dye decolorization

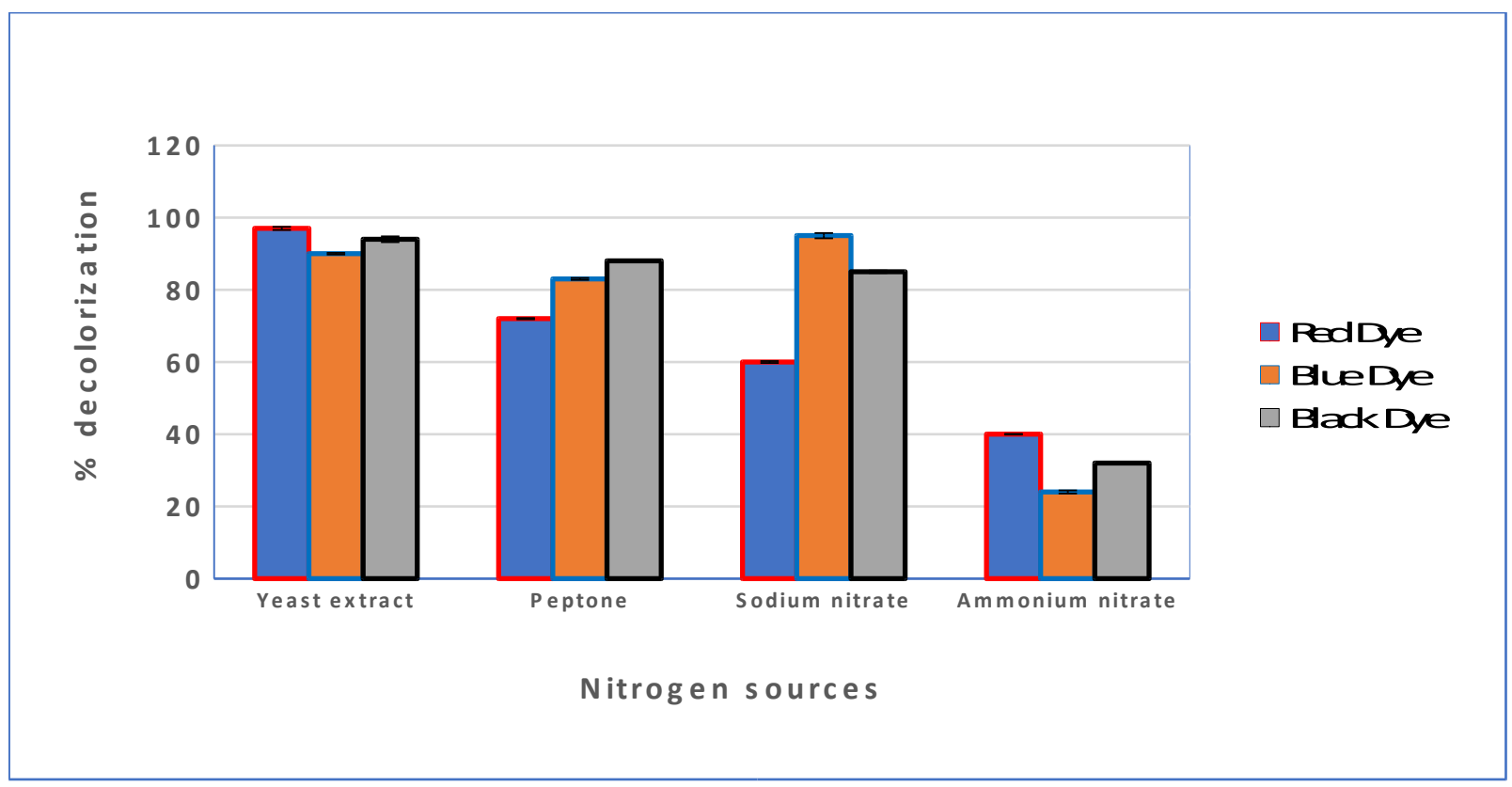


Figure 6: Effect of nitrogen sources on \% dye decolorization

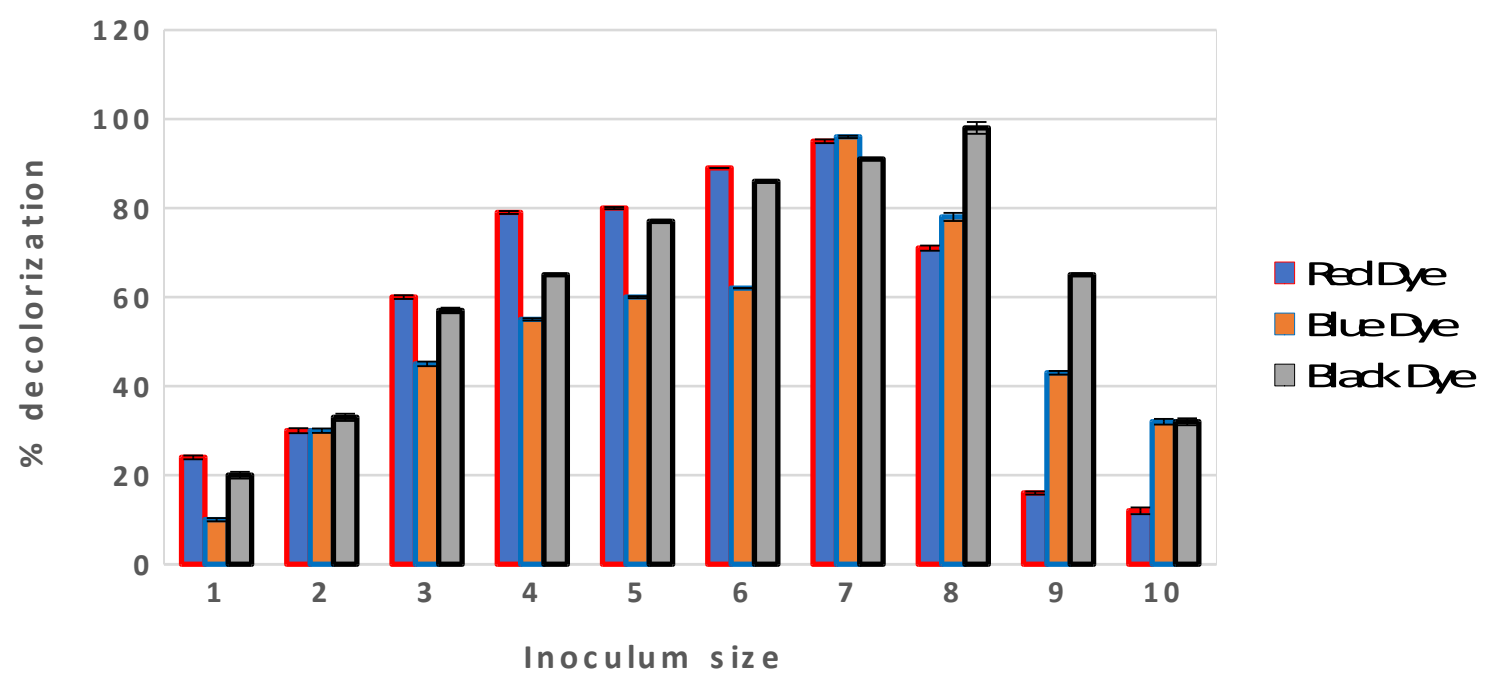

Figure 7: Effect of inoculum size on \% dye decolorization

\section{Calculation of enzyme activity}

Azoreductases are flavoenzymes involved in the biotransformation and detoxification of azo dyes. The isolate showed total enzyme activity $155.32 \mathrm{U}$ ( \pm 0.01 ) and specific enzyme activity 8.08 $\mathrm{U} / \mathrm{mg}$ (blue dye); $153.18 \mathrm{U}( \pm 0.04)$ and $7.97 \mathrm{U} / \mathrm{mg}$ (red dye); $148.72 \mathrm{U}$ ( \pm 0.07 ) and $7.74 \mathrm{U} / \mathrm{mg}$ (black dye). The result is similar to a study carried out by Saini et al., 2018 where Bacillus flexus showed total enzyme activity of $154.9 \mathrm{U}$ and specific activity of $6.811 \mathrm{U} \mathrm{mg}^{-1}$.

\section{Discussion}

Our isolate showed a better decolorization efficiency as compared to the other dye decolorization studies conducted. Junnarkar et al., 2006 selected a novel bacterial consortium that exhibited $90 \%$ decolorization ability within 35 h. Maximum rate of decolorization was observed at $\mathrm{pH} 7.0$, incubation temperature of $37^{\circ} \mathrm{C}$ at 200 $\mathrm{mg} \mathrm{l}^{-1}$ concentration of Direct Red 81 dye when starch $\left(0.6 \mathrm{~g} \mathrm{l}^{-1}\right)$ and casein $\left(0.9 \mathrm{~g} \mathrm{l}^{-}\right.$ 1) were supplemented in the medium. Kumar et al., 2009 reported $98 \%$ decolorization at 25 ppm concentration of dye Remazol Black B after 18 hours of incubation at $\mathrm{pH}$ between 7-8, temperature $30^{\circ} \mathrm{C}$ at $10 \%(\mathrm{v} / \mathrm{v})$ inoculum and $1 \%(\mathrm{w} / \mathrm{v})$ glucose concentration. Pseudomonas sp. and Bacillus sp. isolated from the textile effluent showed maximum Orange $3 R$ dye decolorization 2021 May Edition | www.jbino.com | Innovative Association 
of $89 \%$ at the end of $144 \mathrm{~h}$ under optimum conditions with Bacillus sp. being the most efficient decolorizer (Ponraj et al., 2011). A bacterial consortium exhibited $97 \%$ decolorization in Direct Blue 151 whereas $95 \%$ in Direct Red 31 within 72 hours at $\mathrm{pH} 9.5$, incubation temperature $36^{\circ} \mathrm{C}$ at $200 \mathrm{mg} / \mathrm{l}$ dye concentration with medium supplemented with sucrose and yeast extract (Lalnunhlimi and Krishnaswamy, 2016).

\section{Conclusion}

The isolated Bacillus sp. showed enormous potential to decolorize all the three textile dyes studied even at high concentration of the dyes and could be effectively utilized "for treatment of dye contaminated textile effluents before discharge into environment. The decolorization efficiency of this versatile strain was found to be enhanced by varying $\mathrm{pH}$, temperature, inoculum size, carbon and nitrogen sources. In further work, genetic makeup of the isolated Bacillus sp. can be identified which might further be helpful in enhancing the dye decolorization efficiency of the isolated strain.

\section{Declarations}

\section{Conflict of Interest: None}

Authors' contributions: The $1^{\text {st }}$ author contributed to the concept, work plan, analysis of data and writing of manuscript. $2^{\text {nd }}$ author did the survey, sample collection and lab work. Both authors read and approved the final manuscript.

Funding: None. The authors provided personal resources for funding this work

\section{Acknowledgements}

The authors are thankful to Dolphin (PG) Institute of Biomedical and Natural Sciences, Dehra Dun, Uttarakhand, India, for providing the necessary laboratory requirements and facilities to carry out this work.

\section{References}

Ajaz, M., Rehman, A., Khan, Z., Nisar, M.A., \& Hussain, S. (2019). Degradation of azo dyes by Alcaligenes aquatilis $3 \mathrm{c}$ and its potential use in the wastewater treatment. $A M B$ Express, 9(1), 64-75. https://doi.org/10.1186/s13568-0190788-3

Anjaneyulu, Y., Chary, N. S., \& Raj, D. S. S. (2005). Decolourization of industrial effluents-available methods and emerging technologies-a review. Reviews in Environmental Science and Biotechnology, 4(4), 245-273. https://doi.org/10.1007/s11157-005$1246-z$

Chen, K. C., WU, J. Y., Liou, D. J., \& Hwang, S. C. J. (2003). Decolorization of the textile dyes by newly isolated bacterial strains. Journal of Biotechnology, 101(1), 57-68. https://doi.org/10.1016/s01681656(02)00303-6

Coughlin, M. F., Kinkle, B. K., \& Bishop, P. L. (2002). Degradation of acid orange 7 
in an aerobic biofilm. Chemosphere, 46(1), 11-19. https://doi.org/10.1016/s00456535(01)00096-0

Fu, Y., \& Viraraghavan, T. (2001). Fungal decolorization of dye wastewaters: a review. Bioresource technology, 79(3), 251-262.

https://doi.org/10.1016/s09608524(01)00028-1

Gurulakshmi, M., Sudarmani, D. N. P., \& Venba, R. (2008). Biodegradation of leather acid dye by Bacillus subtilis. Advanced Biotechnology, 7, 12-19.

Jadhav, J. P., Parshetti, G. K., Kalme, S. D., \& Govindwar, S. P. (2007). Decolourization of azo dye methyl red by Saccharomyces cerevisiae MTCC 463. Chemosphere, 68(2), 394-400. https://doi.org/10.1016/i.chemospher e.2006.12.087

Joshi, S., \& Saxena, N. (2018). Bacterial Decolorization of Reactive Red: Strategic Bioremediation of Textile Dye. International Journal of Current Microbiology and Applied Sciences, 7(9), 147-156. https://doi.org/10.20546/ijcmas.2018.7 $\underline{09.019}$

Junior, J. C. V., Cavalcanti, D. L., Alves da Silva, C. A., Andrade, R. F., \& Campos-Takaki, G. M. (2015). Decolorization of Black $B$ azo dye by Pseudomonas aeruginosa. International Journal of Current Microbiology and Applied Sciences, 7, 720-728.

Junnarkar, N., Murty, D. S., Bhatt, N. S., \& Madamwar, D. (2006). Decolorization of diazo dye Direct Red 81 by a novel bacterial consortium. World Journal of Microbiology and Biotechnology, 22(2),

163-168.

https://doi.org/10.1007/s1 1274-005-

9014-3

Kalyani, D. C., Telke, A. A., Dhanve, R. S., \& Jadhav, J. P. (2009). Ecofriendly biodegradation and detoxification of Reactive Red 2 textile dye by newly isolated Pseudomonas sp. SUK1. Journal of Hazardous Materials, 163/23),

735-742.

https://doi.org/10.1016/i.jhazmat.2008 .07 .020

Keharia, H., \& Madamwar, D. (2003). Bioremediation concepts for treatment of dye containing wastewater: A review. Indian Journal of Experimental Biology, 41(9), 10681075.

Kumar, K., Dastidar, M. G., \& Sreekrishnan, T. R. (2009). Effect of process parameters on aerobic decolourization of reactive azo dye using mixed culture. World Academy of Science, Engineering and Technology, 58, 952-955.

Lalnunhlimi, S., \& Krishnaswamy, V. (2016). Decolorization of azo dyes (Direct Blue 151 and Direct Red 31) by moderately alkaliphilic bacterial consortium. Brazilian Journal of Microbiology, 47(1), 39-46. https://doi.org/10.1016/j.bjm.2015.11.0 $\underline{13}$

Liger, D., Graille, M., Zhou, C.Z., Leulliot, N., Quevillon-Chervel, S., Blondeau, K., Janin, J., \& van Tilbeurgh, H. (2004). 
Crystal structure and functional characterization of yeast YLRO11wp, an enzyme with NAD (P) H-FMN and ferric iron reductase activities. Journal of Biological Chemistry, 279(33), 34890-34897.

\section{https://doi.org/10.1074/jbc.m4054042}

$\underline{00}$

Lowry, O. H., Rosebrough, N. J., Farr, A. L., \& Randall, R. J. (1951). Protein measurement with the Folin phenol reagent. Journal of Biological Chemistry, 193, 265-275. https://doi.org/10.1016/s00219258(19)52451-6

Moosvi, S., Keharia, H., \& Madamwar, D. (2005). Decolourization of textile dye Reactive Violet 5 by a newly isolated bacterial consortium RVM 11.1. World Journal of Microbiology and Biotechnology, 21(5), 667-672. https://doi.org/10.1007/s1 1274-0043612-3

Ndasi, N. P., Augustin, M., \& Bosco, T. J. (2011). Biodecolourisation of textile dyes by local microbial consortia isolated from dye polluted soils in ngaoundere (Cameroon). International Journal of Environmental Science, 1(7), 1403-1419.

Ogugbue, C. J., \& Sawidis, T. (2011). Bioremediation and detoxification of synthetic wastewater containing triarylmethane dyes by Aeromonas hydrophila isolated from industrial effluent. Biotechnology Research International, 2011, 1-11. https://doi.org/10.4061/2011/967925
Parshetti, G., Kalme, S., Saratale, G., \& Govindwar, S. (2006). Biodegradation of Malachite Green by Kocuria rosea MTCC 1532. Acta Chimica Slovenica, 53(4), 492-498.

Patel, R., Chauhan, P. B., \& Gahlout, M. (2017). Enhanced decolorization and degradation study of red H8B dye by bacterial isolate R5. International Journal of Drug Research and Technology, 6(2), 87-95.

Ponraj, M., Gokila, K., \& Zambare, V. (2011). Bacterial decolorization of textile dye-Orange 3R. International journal of advanced biotechnology and research, 2(1), 168-177.

Pratiwi, D., Indrianingsih, A.W., \& Darsih, C. (2017, December). Decolorization and Degradation of Batik Dye Effluent using Ganoderma lucidum. IOP Conference Series: Earth and Environmental Science, 101/1), 012034 IOP Publishing. https://doi.org/10.1088/1755-

1315/101/1/012034

Ramasany, R., Ahmed, H. A. M., \& Karthik, S. S. (2012). Development of microbial consortium for the biodegradation and biodecolorization of textile effluents. Journal of Urban and Environmental Engineering, 6(1), 3641.

https://doi.org/10.4090/juee.2012.v6n 1.036041

Saini, S., Battan, B., Maan, S., \& Sharma, J. (2018). Decolourization of dyes by Alcaligenes faecalis and Bacillus flexus isolated from textile effluent. 
Indian Journal of Experimental Biology, 56 (11), 820-826.

Sani, R. K., \& Banerjee, U. C. (1999). Decolorization of triphenylmethane dyes and textile and dye-stuff effluent by Kurthia sp. Enzyme and Microbial Technology, 24(7), 433-437. https://doi.org/10.1016/s0141-

\section{$\underline{0229(98) 00159-8}$}

Shah, M. P., Patel, K. A., Nair, S. S., \& Darji, A. M. (2014). Microbial degradation and decolorization of reactive dyes by Bacillus spp. ETL-1979. American Journal of Microbiological Research, 2(1), 16-23. https://doi.org/10.12691/ajmr-2-1-3 